\title{
Hubungan Antara Kemampuan Adaptasi Terhadap Kebisingan Dengan Stres Kerja Karyawan ${ }^{1}$
}

\author{
Ruly Asmarani ${ }^{2}$ \\ Dinas Pendidikan Kab. Banjar
}

\begin{abstract}
Today stress has become a very important management issue in the industrial world. Nearly everyone experiences stress with respect to work. No matter how small the work stress that emerges must be addressed so as not to enlarge which ultimately can harm the organization and employees. One source of work stress is the noise that is not desired by the ear because it can be annoying and irritating. But the noise can be responded differently by each individual according to their adaptability. If the individual is less able to adapt to the noise then he will tend to experience stress.
\end{abstract}

This study aims to determine the relationship between the ability to adapt to noise with employee work stress. This research was designed using a quantitative and correlational approach. Population of this research is employees of production of PT. Hendratna Plywood totaling 357 people. In sampling, the researcher used Random Sampling Technique by taking 60 employees. In this study the researchers used pure try out. The result of try out scale of ability of adaptation to noise obtained 23 valid items from 30 items presented. While on work stress scale obtained 55 valid items from 72 items.

The results showed that 32 subjects (53.3\%) experienced high work stress and 28 subjects $(46.6 \%)$ experienced low work stress. It also found that 37 subjects (61.6\%) had good adaptability to noise and 23 subjects (38.3\%) had poor adaptability to noise. The result of data analysis is known that there is a significant negative relationship between the ability of adaptation to noise with employee work stress shown by correlation coefficient $r=-0,359$ and $p=0,005$. This means that if employees have good adaptability to noise then low job stress, otherwise if employees have poor adaptability to noise then high job stress. From this it can be seen that the ability of adaptation to noise gives effective contribution of $12,88 \%\left(r^{2}=0,1288\right)$ to work stress, while the rest $87,12 \%$ influenced by other factor.

Kata Kunci: Kemampuan Adaptasi Terhadap Kebisingan, Stres kerja

${ }^{1}$ Tulisan ini di dasarkan pada skripsi penulis pada Program Studi Sarjana Fakultas Psikologi Universitas Muhammadiyah Malang.

${ }^{2}$ Korespondensi untuk tulisan ini ditujukan kepada penulis pertama email asmarani.psi@yahoo.co.id 


\section{Pendahuluan}

Pada era millennium ini, kemajuan industri dan kemajuan teknologi berkembang semakin pesat, hal ini dapat terlihat dari banyaknya pemakaian mesin-mesin yang dapat mengolah dan memproduksi barang atau bahan yang dibutuhkan oleh manusia secara cepat. Dewasa ini stres telah menjadi masalah manajemen yang sangat penting di dunia. Tiga dari lima orang menyatakan bahwa stres kerja berhubungan langsung dengan masalah kesehatan akut dan kronis sehingga dalam laporan pemerintah Amerika Serikat di tahun 1992, "stres kerja" dijuluki sebagai "penyakit abad ke-20". ${ }^{3}$ Diperkirakan bahwa sekitar $15 \%$ dari seluruh manusia menderita semacam gejala stres psikologis pada suatu ketika dalam hidupnya dan banyak diantaranya disebabkan oleh persoalan yang ditimbulkan oleh pekerjaan. ${ }^{4}$

Nahhari, ${ }^{5}$ pada penelitiannya tentang tingkat stres kerja pada Karyawan Unit Pengolahan V Pertamina Balikpapan menyimpulkan bahwa tingkat stres kerja yang dialami karyawan termasuk dalam kategori tinggi yaitu sebesar 7,7 \%, sedang sebesar 78,5\%, sedangkan yang rendah sebesar 13,8 \%. Dan sumber yang lebih mendominasi dari tingkat stres kerja pada karyawan tersebut yaitu lingkungan kerja.

Penelitian tentang stres kerja yang dilakukan oleh Evans dan Johnson, ${ }^{6}$ menemukan bahwa kebisingan kantor intensitas rendah dapat menghasilkan indeks-indeks fisiologis dan motivasional stres. Akibatnya karyawan mengalami penurunan performa tugas pasca bising yang diakibatkan oleh tertekannya motivasi dan penurunan penggunaan sarana perabot kerja ergonomic yang di rancang untuk memberikan kesempatan untuk penyesuaian postur tubuh selama bekerja. Adapun stres fisiologis yang dialami karyawan antara lain tekanan darah tinggi, penyakit jantung, sakit kepala dan lain-lain. Hal ini mempengaruhi produktivitas dan kepuasan karyawan tersebut.

\footnotetext{
${ }^{3}$ National Safety Council, Manajemen Stres (Jakarta: EGC, 2004). 6.

${ }^{4}$ M. Lucas dan K. Wilson, Memelihara Gairah Kerja (Jakarta: Arcan, 1992). 14.

${ }^{5}$ S. Nahhari, "Tingkat Stres Kerja pada Karyawan Unit Pengolahan V Pertamina Balikpapan" (Skripsi, Fakultas Psikologi Universitas Muhammadiyah Malang, 2003).

${ }^{6}$ Gary W Evans dan Dana Johnson, "Stress and open-office noise.," Journal of applied psychology 85, no. 5 (2000). 779.
} 
Ardani $^{7}$ telah meneliti tentang hubungan antara persepsi tentang keselamatan kerja dan kesehatan kerja dengan stres kerja pada pekerja di Pertamina Unit Pengolahan VI Balongan Indramayu Jawa Barat. Hasil penelitian menunjukkan bahwa ada hubungan yang negatif antara persepsi tentang keselamatan dan kesehatan pekerja dengan stres kerja, yang artinya apabila persepsi tentang keselamatan dan kesehatan pekerja tinggi maka stres kerjanya rendah. Sebaliknya apabila persepsi tentang keselamatan dan kesehatan pekerja rendah maka stres kerja tinggi.

Stres kerja merupakan bagian dari kehidupan individu dan organisasi. Sekecil apapun stres kerja yang muncul harus segera ditanggulangi agar tidak membesar, yang akhirnya dapat merugikan organisasi maupun karyawan. Seperti yang diungkapkan oleh Diahsari, ${ }^{8}$ dalam penelitiannya bahwa stres kerja memberikan kontribusi pada produktivitas kerja yang juga berpengaruh pada prestasi kerja.

Hampir semua orang di dalam kehidupan mengalami stres sehubungan dengan pekerjaan mereka. Tidak jarang situasi dan kondisi yang bisa menimbulkan stres ini kecil saja dan tidak berarti, tetapi bagi banyak orang situasi stres itu begitu sangat terasa dan berkelanjutan di dalam jangka waktu yang lama. Kondisi-kondisi yang cenderung menyebabkan stres di sebut stressors. Ada sejumlah kondisi kerja yang sering menyebabkan stres kerja bagi para karyawan. Salah satu kondisi kerja tersebut adalah kondisi fisik lingkungan kerja yaitu adanya kebisingan.

Menurut batasannya, kebisingan adalah suara-suara yang tidak dikehendaki, oleh karenanya kebisingan seringkali mengganggu aktivitas apalagi jika kebisingan itu bernada tinggi. Menurut Sarwono 9 secara psikologik, bising adalah penimbul stres (stressor).

Dari hasil survey yang dilakukan oleh Stefan Willich dari Charite Medical Center di Berlin menunjukkan bahwa suara berkekuatan tinggi atau bising mampu menyebabkan serangan jantung. Dari 4000 orang pasien yang ditelitinya, mereka yang biasa dan hidup di lingkungan yang ramai secara terus-menerus mempunyai risiko serangan jantung hingga $50 \%$ lebih tinggi dari pada mereka yang jauh dari suara-suara yang berkekuatan tinggi.

\footnotetext{
${ }^{7}$ Tristadi Ardi ARDANI dan Sri Rahayu Partosuwido, “Hubungan antara persepsi tentang keselamatan kerja dan kesehatan kerja dengan stres kerja pada pekerja di Pertamina Unit Pengolahan (UP) VI Balongan Indramayu Jawa Barat," Jurnal APIO, 2005.

${ }^{8}$ Erita Y. Diahsari, “Kontribusi stres pada produktivitas kerja," Jurnal ANIMA 16, no. 4 (2001). 360.

${ }^{9}$ Sarlito W. Sarwono, Psikologi Lingkungan (Jakarta: PT. Gramedia Widiasarana Indonesia, 1995). 93.
} 
Willich menemukan bahwa kebiasaan terus-menerus mendengarkan suara-suara yang ramai baik di lingkungan kerja maupun rumah mampu meningkatkan level hormon stres.

Hasil penelitian Cohen (1969), Miller (1974) dan Strakov (1996) di bidang industri mencatat bahwa kebisingan dalam intensitas tinggi berhubungan dengan sakit kepala, kebencian (perasaan muak), ketidakstabilan emosi, kehilangan daya argumentasi (blo'on), kecemasan, impotensi seksual, dan perubahan suasana hati. ${ }^{10}$

Badan Kesehatan Dunia (WHO) melaporkan tahun 1988 terdapat 8 - $12 \%$ penduduk dunia menderita dampak kebisingan dalam berbagai bentuk. Angka itu diperkirakan akan terus meningkat. Sebagai contoh di luar negeri, Royal National Institute For Deaf People (RNID) yaitu sebuah lembaga kehormatan Inggris yang meneliti masalah ketulian, mensurvai sejumlah klab malam yang ternyata tingkat kebisingannya mencapai $120 \mathrm{~dB}$, hal itu mengakibatkan ketulian pada anak-anak muda yang mengunjungi klab malam tersebut karena telinga anak-anak muda disajikan suara yang jauh di atas ambang batas selama berjam-jam.

Selain itu pada dunia industri, ditemukan hampir $40 \%$ kaum pekerja pada Call Center mengidap Tinnitus, yaitu bunyi denging di telinga yang sering muncul tiba-tiba. Meskipun denging telinga tersebut akan hilang dalam beberapa jam, namun bisa dijadikan sebagai indikator rusaknya pendengaran. Hal tersebut tidak lain diakibatkan oleh bunyi gaduh yang terdengar lewat headset saat melayani panggilan pelanggan.

Kebisingan selain dapat menimbulkan gangguan sementara atau tetap pada alat pendengaran, juga merupakan sumber stres yang menyebabkan peningkatan dari kesiagaan dan ketidakseimbangan psikologis. Ivancevich dan Matteson (1980) berpendapat bahwa bising yang berlebih (sekitar 80 desibel) yang berulangkali di dengar, untuk jangka waktu lama, dapat menimbulkan stress. ${ }^{11}$

Melihat beberapa fenomena tentang kebisingan di atas, maka dapat diketahui bahwa kebisingan merupakan suatu kondisi lingkungan tertentu yang kehadirannya tidak diharapkan dan berpengaruh secara negatif terhadap aktivitas individu atau kelompok masyarakat. Selain itu kebisingan merupakan salah satu jenis rangsang lingkungan yang dapat di respon berbeda oleh setiap individu yang mengalaminya. Perubahan respon

\footnotetext{
${ }^{10}$ Oman Sukmana, Dasar-dasar Psikologi Lingkungan (Malang: Bayu Media \& UMM Press, 2003). 89.

${ }^{11}$ A. S Munandar, Psikologi Industri dan Organisasi. (Jakarta: Penerbit Universitas Indonesia (UI-Press), 2001). 382.
} 
seseorang terhadap kebisingan yang dialaminya menunjukkan kemampuan adaptasinya terhadap lingkungan.

Seperti yang terjadi di pabrik milik PT. Hendratna Plywood, yang berlokasi di Kotamadya Banjarmasin, Propinsi Kalimantan Selatan. Bidang usahanya adalah pengusahaan hutan (logging), pengusahaan Hutan Tanaman Industri Transmigrasi, industri plywood dan secondary process plywood. Para karyawan di bagian produksi PT.Hendratna Plywood setiap hari harus bekerja dalam lingkungan pabrik yang sangat bising yang disebabkan dari suara operasi mesin dan aktivitas karyawannya. Beberapa karyawan merasa suasana bising di dalam pabrik tersebut sangat mengganggu pekerjaan, selain itu juga membuat mereka mudah merasa cemas dan sering sakit kepala, namun karyawan lain menganggap suasana bising tersebut tidak mengganggu.

Dari uraian latar belakang di atas maka peneliti tertarik untuk meneliti "Hubungan Antara Kemampuan Adaptasi Terhadap Kebisingan Dengan Stres Kerja Karyawan". Dari hasil penelitian diharapkan dapat memberikan sumbangan ilmiah untuk mengembangkan Psikologi Industri dan Organisasi dan Psikologi Lingkungan. Hasil dari penelitian ini diharapkan dapat berguna bagi perusahaan dalam rangka pengelolaan sumber daya manusia untuk meningkatkan kesehatan dan kualitas kerja karyawan.

\section{Metode}

\section{Rancangan Penelitian}

Penelitian ini merupakan penelitian non eksperimental, sebab peneliti tidak memberikan perlakuan khusus pada variabel tertentu, dalam hal ini adalah melakukan manipulasi dengan mengontrol variabel bebas.

Rancangan penelitian ini berupa rancangan korelasional, dimana penelitian bermaksud untuk menghubungkan dua variabel yang berbeda. 


\section{Variabel Penelitian}

Variabel adalah suatu sifat yang dapat memiliki berbagai macam nilai. Lebih lanjut dikatakan bahwa variabel adalah simbol atau lambang yang padanya dilekatkan bilangan atau nilai. ${ }^{12}$

Adapun jenis variabel yang digunakan dalam penelitian ini adalah :

1. Variabel bebas

2. Variabel terikat
: Kemampuan Adaptasi terhadap Kebisingan

: Stres Kerja

\section{Definisi Operasional}

Dalam penelitian ini definisi operasional variabel penelitian yang dipergunakan adalah sebagai berikut:

1. Kemampuan Adaptasi terhadap Kebisingan

Kemampuan adaptasi terhadap kebisingan adalah kesanggupan individu untuk dapat menyesuaikan diri terhadap bunyi yang tidak dikehendaki oleh telinga, yang di ungkap dengan menggunakan skala kemampuan adaptasi terhadap kebisingan meliputi kemampuan menerima volume suara diatas $90 \mathrm{~dB}$, kemampuan perkiraan dan kemampuan kontrol dari individu terhadap kebisingan, dan di ukur dengan melihat skor totalnya. Skor total yang tinggi menunjukkan kemampuan adaptasi yang baik terhadap kebisingan, sedangkan skor total yang rendah menunjukkan kemampuan adaptasi yang kurang baik terhadap kebisingan.

2. Stres kerja

Stres kerja adalah suatu kondisi ketegangan yang dialami individu terhadap situasi dan kondisi di dalam lingkungan kerja yang mempengaruhi emosi, proses berpikir dan kondisi seseorang. Stres kerja di ungkap dengan menggunakan skala stres kerja yang meliputi sumber-sumber stres kerja (faktor-faktor intrinsik dalam pekerjaan yaitu tuntutan fisik dan tuntutan tugas, peran individu dalam organisasi, pengembangan karier, hubungan dalam pekerjaan, struktur dan iklim organisasi) dan gejala-gejala stres kerja (fisiologis, psikologis dan perilaku). Stres kerja di ukur dengan melihat skor

\footnotetext{
${ }^{12}$ F.N. Kerlinger, Asas-asas Penelitian Behavioral (Yogyakarta: Gadjah Mada University Press, 2003). 49.
} 
totalnya. Skor total yang tinggi menunjukkan stres kerja yang tinggi, sedangkan skor total yang rendah menunjukkan stres kerja yang rendah

\section{Populasi dan Sampel}

Populasi dari penelitian ini adalah karyawan bagian produksi PT. Hendratna Plywood yang berjumlah 598 orang, dengan alasan bahwa karyawan bagian produksi PT. Hendratna Plywood setiap hari bekerja di lingkungan yang bising dengan tingkat kebisingan rata-rata $90 \mathrm{~dB}$.

Teknik penentuan sampel pada penelitian ini menggunakan pendapat Arikunto $^{13}$ yang memberikan pedoman untuk menentukan besarnya sampel dari suatu populasi yaitu apabila subyeknya kurang dari 100, lebih baik diambil semua sehingga penelitiannya merupakan penelitian populasi. Selanjutnya, jika jumlah subyeknya besar dapat di ambil antara $10-15 \%$ atau $20-25 \%$ atau lebih.

Teknik pengambilan sampel dalam penelitian ini dengan menggunakan Teknik Sampel Random, yaitu dilakukan dengan jalan "mencampur" subyek-subyek di dalam populasi sehingga semua subyek di anggap sama. ${ }^{14}$ Sampel yang digunakan dalam penelitian ini berjumlah 100 orang karyawan, dan di ambil dengan cara undian.

\section{Jenis Data dan Instrumen Penelitian}

Jenis data yang digunakan dalam penelitian ini adalah data interval, yaitu data yang didalamnya terdapat angka skala yang batas variasi nilai satu dengan yang lain memiliki jarak yang sama, ${ }^{15}$ sedangkan jenis dari penelitian ini adalah penelitian kuantitatif, sebab data-data dari penelitian ini adalah berupa angka atau gejala-gejala yang diangkakan. ${ }^{16}$

\footnotetext{
${ }^{13}$ Suharsimi Arikunto, “Metode penelitian," Jakarta: Rineka Cipta, 2002. 120.

${ }^{14}$ Suharsimi Arikunto, Prosedur Penelitian Suatu Pendekatan Praktek. Edisi revisi IV (Jakarta: PT. Rineka Cipta, 2002). 120.

${ }^{15}$ Tulus Winarsunu, Statistik dalam Penelitian Psikologi Pendidikan (Malang: UMM Press, 2002). 9.

${ }^{16}$ E. Poerwanti, Dimensi-dimensi Riset Ilmiah (Malang: UMM Press, 2000). 26.
} 
Salah satu proses penting dalam penelitian adalah pengumpulan data. Untuk menghasilkan data yang dihasilkan secara tepat, yaitu data yang relevan dengan tujuan penelitian dan memiliki validitas serta reliabilitas sebaik mungkin, maka metode yang digunakan dalam pengumpulan data penelitian adalah metode skala. ${ }^{17}$

Metode pengumpulan data yang digunakan dalam penelitian ini adalah dengan menggunakan skala Likert. Dalam penggunaan skala psikologi stimulusnya berupa pertanyaan atau pernyataan tidak langsung mengungkap atribut yang hendak di ukur melainkan mengungkap indikator perilaku dari atribut yang bersangkutan. Dalam hal ini meskipun subyek yang di ukur memahami pertanyaan atau pernyataan namun tidak mengetahui arah jawaban yanag dikehendaki oleh pertanyaan yang diajukan sehingga jawaban yang diberikan akan tergantung pada interpretasi subyek terhadap pertanyaan tersebut dan jawabannya lebih bersifat proyektif, yaitu berupa proyeksi dari perasaan atau kepribadiannya. ${ }^{18}$

Instrumen yang akan digunakan dalam penelitian ini terdiri atas 2 skala yang diberikan kepada subyek penelitian, yaitu skala kemampuan adaptasi terhadap kebisingan (skala A) dan skala stres kerja (skala B).

a. Skala Kemampuan Adaptasi terhadap Kebisingan

Dalam membuat skala kemampuan adaptasi terhadap kebisingan akan didasarkan pada aspek-aspek karakteristik gangguan dari kebisingan menurut teori Kryter (1970) serta Glass dan Singer (1972) yang dikutip oleh Sukmana, ${ }^{19}$ yaitu :

1. Volume

Volume suara yang berbeda akan mempengaruhi manusia. Volume suara di atas $90 \mathrm{~dB}$ bukan saja akan menimbulkan gangguan psikologis akan tetapi apabila diulang-ulang secara periodik setiap harinya antara 8 jam atau lebih akan menimbulkan dampak fisiologis berupa gangguan pada syaraf pendengaran. Kelebihan pendengaran akan menimbulkan gangguan terhadap kemampuan komunikasi verbal.

\footnotetext{
${ }^{17}$ F.N. Kerlinger, Asas-asas Penelitian Behavioral. 190.

${ }^{18}$ Saifuddin Azwar, Sikap Manusia. Teori dan Pengukurannya, 2 ed. (Yogyakarta: Pustaka Pelajar, 2003). 3.

${ }^{19}$ Oman Sukmana, Dasar-dasar Psikologi Lingkungan. 83.
} 
2. Kemampuan meramalkan (predictability)

Suatu kebisingan yang kejadiannya tidak di prediksi (tidak diperkirakan) akan menimbulkan gangguan yang lebih besar daripada kebisingan yang sebelumnya sudah di prediksi (diperkirakan) sebagai kebisingan yang akan terjadi secara tetap. Kebisingan yang biasa di dengar oleh seseorang mungkin saja bukan merupakan gangguan.

3. Kontrol (pengendalian)

Faktor pengendalian hubungannya dengan faktor perkiraan. Tidak adanya kendali pada kebisingan akan menimbulkan stres yang jika berlangsung lama yang pada akhirnya bisa menimbulkan reaksi learned helplessness (ketidak berdayaan yang dipelajari) artinya, orang menjadi tidak berdaya dan membiarkan saja bising itu walaupun stresnya bertambah besar.

Tabel 1.

Blue print skala kemampuan adaptasi terhadap kebisingan sebelum try out

\begin{tabular}{llrcc}
\hline No & Indikator & \multicolumn{2}{c}{ Butir Item } & Jumlah \\
\cline { 3 - 4 } & & Favorable & Unfavorable & \\
$\mathbf{1}$ & Volume & $1,7,13,19,25$ & $4,10,16,22,28$ & $\mathbf{1 0}$ \\
$\mathbf{2}$ & Perkiraan & $2,8,14,20,26$ & $5,11,17,23,29$ & $\mathbf{1 0}$ \\
$\mathbf{3}$ & Kontrol & $3,9,15,21,27$ & $6,12,18,24,30$ & $\mathbf{1 0}$ \\
\hline & Total & $\mathbf{1 5}$ & $\mathbf{1 5}$ & $\mathbf{3 0}$ \\
\hline
\end{tabular}

Setelah diadakan try out pada skala kemampuan adaptasi terhadap kebisingan, maka item yang tidak valid akan di buang dan sebagai acuan untuk membuat skala kemampuan adaptasi terhadap kebisingan pada penelitian ini akan digunakan blue print dibawah ini : 
Tabel 2.

Blue print skala kemampuan adaptasi terhadap

kebisingan setelah try out

\begin{tabular}{|c|c|c|c|c|}
\hline \multirow[t]{2}{*}{ No } & \multirow[t]{2}{*}{ Indikator } & \multicolumn{2}{|c|}{ Butir Item } & \multirow[t]{2}{*}{ Jumlah } \\
\hline & & Favorable & Unfavorable & \\
\hline 1 & Volume & $1,611,13$ & $4,8,11,16,21$ & 9 \\
\hline 2 & Perkiraan & $2,7,10,14,19$ & $5,17,22$ & 8 \\
\hline 3 & Kontrol & $3,15,20$ & $12,18,23$ & 6 \\
\hline & Total & 12 & 11 & 23 \\
\hline
\end{tabular}

b. Skala stres kerja

Skala kedua (B) untuk mengukur stres kerja mengacu pada pendapat Munandar ${ }^{20}$ yang dikelompokkan dalam lima kategori yaitu sebagai berikut:

1. Faktor-Faktor Intrinsik Dalam Pekerjaan

a. Tuntutan Fisik

Kondisi fisik kerja mempunyai pengaruh terhadap kondisi faal dan psikologis diri seorang tenaga kerja.

b. Tuntutan Tugas

Beban kerja berlebih dan beban kerja terlalu sedikit merupakan pembangkit stres, beban kerja dapat dibedakan secara kuantitatif dan kualitatif.

\section{Peran Individu dalam Organisasi}

Setiap tenaga kerja bekerja sesuai dengan perannya dalam organisasi, artinya setiap tenaga kerja memiliki kelompok tugasnya yang harus ia lakukan sesuai dengan aturanaturan yang ada dan sesuai dengan yang diharapkan atasan. Kurang baik berfungsinya (dysfunction) peran, yang merupakan pembangkit stres seperti konflik peran, dan kebingungan peran (role ambiguity).

${ }^{20}$ A. S Munandar, Psikologi Industri dan Organisasi. 381. 


\section{Pengembangan Karier}

Pengembangan karier merupakan pembangkit stres potensial yang mencakup ketidakpastian pekerjaan, promosi berlebih, dan promosi yang kurang.

\section{Hubungan dalam Pekerjaan}

Harus hidup dengan orang lain, menurut Seyle, merupakan salah satu aspek dari kehidupan yang penuh stres.

\section{Struktur dan Iklim Organisasi}

Faktor stres yang dikenali dalam kategori ini berpusat pada sejauh mana tenaga kerja dapat terlibat atau berperan serta dan pada support social.

Selain itu juga mengacu pada pendapat Robbins ${ }^{21}$ mengenai gejala stres yaitu yang dikelompokkan menjadi tiga kategori, yaitu :

\section{a. Gejala Fisiologis}

Gejala fisiologis ditandai dengan perubahan dalam metabolisme tubuh, meningkatknya laju detak jantung dan pernapasan, meningkatknya tekanan darah, timbul sakit kepala, dan menyebabkan serangan jantung.

\section{b. Gejala Psikologis}

Gejala psikologis ditandai dengan berkurangnya kepuasan dalam bekerja, ketegangan, kecemasan, mudah marah, kebosanan, dan suka menunda-nunda.

c. Gejala Perilaku

Gejala perilaku ditandai dengan perubahan dalam produktivitas, absensi, dan tingkat keluarnya karyawan, juga perubahan dalam kebiasaan makan, meningkatnya merokok dan konsumsi alkohol, bicara cepat, gelisah dan gangguan tidur.

\footnotetext{
${ }^{21}$ S.P. Robbins, Perilaku Organisasi (Jakarta: PT INDEKS Kelompok Gramedia, 2003). 309.
} 
Tabel 3.

Blue print skala stres kerja sebelum try out

\begin{tabular}{|c|c|c|c|c|c|c|c|c|}
\hline \multirow{3}{*}{$\begin{array}{l}\mathbf{N} \\
\mathbf{o}\end{array}$} & \multirow[t]{3}{*}{ Indikator } & \multicolumn{6}{|c|}{ Gejala stres kerja } & \multirow{3}{*}{$\begin{array}{l}\mathrm{T} \\
\mathrm{o} \\
\mathrm{t} \\
\mathrm{a} \\
1\end{array}$} \\
\hline & & \multicolumn{2}{|c|}{ Fisiologis } & \multicolumn{2}{|c|}{ Psikologis } & \multicolumn{2}{|c|}{ Perilaku } & \\
\hline & & $\mathbf{F}$ & $\mathrm{U}$ & $\mathbf{F}$ & $\mathbf{U}$ & $\mathbf{F}$ & $\mathbf{U}$ & \\
\hline \multirow[t]{3}{*}{1} & $\begin{array}{l}\text { Faktor-faktor } \\
\text { intrinsik dalam } \\
\text { pekerjaan: }\end{array}$ & & & & & & & \\
\hline & - Tuntutan fisik & 1,37 & 7,43 & 13,49 & 19,55 & 25,61 & 31,67 & 12 \\
\hline & - Tuntutan tugas & 2,38 & 8,44 & 14,50 & 20,56 & 26,62 & 32,68 & 12 \\
\hline 2 & $\begin{array}{l}\text { Peran individu } \\
\text { dalam organisasi }\end{array}$ & 3,39 & 9,45 & 15,51 & 21,57 & 27,63 & 33,69 & 12 \\
\hline 3 & $\begin{array}{l}\text { Pengembangan } \\
\text { karier }\end{array}$ & 4,40 & 10,46 & 16,52 & 22,58 & 28,64 & 34,70 & 12 \\
\hline 4 & $\begin{array}{l}\text { Hubungan dalam } \\
\text { pekerjaan }\end{array}$ & 5,41 & 11,47 & 17,53 & 23,59 & 29,65 & 35,71 & 12 \\
\hline 5 & $\begin{array}{l}\text { Struktur dan iklim } \\
\text { organisasi }\end{array}$ & 6,42 & 12,48 & 18,54 & 24,60 & 30,66 & 36,72 & 12 \\
\hline \multicolumn{2}{|c|}{ Total } & 12 & 12 & 12 & 12 & 12 & 12 & 60 \\
\hline
\end{tabular}

Setelah dilakukan try out, maka sebagai acuan untuk membuat skala stres kerja pada penelitian ini akan digunakan blue print dibawah ini :

Tabel 4.

Blue print skala stres kerja setelah try out

\begin{tabular}{|c|c|c|c|c|c|c|c|c|}
\hline \multirow[t]{3}{*}{ No } & \multirow[t]{3}{*}{ Indikator } & \multicolumn{6}{|c|}{ Gejala stres kerja } & \multirow{3}{*}{$\begin{array}{l}\mathrm{T} \\
\mathbf{o} \\
\mathbf{t} \\
\mathbf{a} \\
1\end{array}$} \\
\hline & & \multicolumn{2}{|c|}{ Fisiologis } & \multicolumn{2}{|c|}{ Psikologis } & \multicolumn{2}{|c|}{ Perilaku } & \\
\hline & & $\mathbf{F}$ & $\mathbf{U}$ & $\mathbf{F}$ & $\mathbf{U}$ & $\mathbf{F}$ & $\mathbf{U}$ & \\
\hline \multirow[t]{3}{*}{1} & $\begin{array}{l}\text { Faktor-faktor } \\
\text { intrinsik dalam } \\
\text { pekerjaan : }\end{array}$ & & & & & & & \\
\hline & - Tuntutan fisik & 1,30 & 6,34 & 11,39 & 17,44 & 22 & 26 & 10 \\
\hline & - Tuntutan tugas & 2,31 & 7,35 & 12 & 18 & 23,47 & 27 & 9 \\
\hline 2 & $\begin{array}{l}\text { Peran individu } \\
\text { dalam organisasi }\end{array}$ & 3,32 & 8,36 & 13,40 & - & 48 & 52 & 8 \\
\hline 3 & $\begin{array}{c}\text { Pengembangan } \\
\text { karier }\end{array}$ & 4 & 9,37 & 14,41 & 19 & 24,49 & 53 & 9 \\
\hline 4 & $\begin{array}{c}\text { Hubungan dalam } \\
\text { pekerjaan }\end{array}$ & 5 & 10 & 20,42 & 20,45 & 25,50 & 28,54 & 10 \\
\hline 5 & $\begin{array}{c}\text { Struktur dan iklim } \\
\text { organisasi }\end{array}$ & 33 & 38 & 16,43 & 21,46 & 51 & 29,55 & 9 \\
\hline & Total & 9 & 10 & 11 & 8 & 9 & 8 & 55 \\
\hline
\end{tabular}


Skala kemampuan adaptasi terhadap kebisingan dan skala stres kerja di susun mengikuti model skala Likert, berisikan poin yang menunjukkan empat pilihan jawaban yaitu sangat setuju, setuju, tidak setuju, dan sangat tidak setuju. Item pernyataan terdiri dari item-item yang bersifat favorable yang mendukung terhadap indikator variabel yang di ungkap dan item-item yang bersifat unfavorable yang menunjukkan tidak mendukung terhadap indikator variabel yang di ungkap.

\section{Uji Validitas dan Realibilitas}

Perhitungan validitas ini dilakukan dengan menggunakan program komputer SPSS 11.0 for Windows. Validitas instrumen di peroleh dari hasil korelasi antara item yang dikorelasikan dengan skor total kemudian dibandingkan dengan nilai $\mathrm{r}$ tabel pada tingkat signifikansi $5 \%$. Jika dari hasil perhitungan validitas item dalam satu faktor didapatkan nilai korelasi item lebih besar dari nilai $\mathrm{r}$ tabel $(=0,31)$, maka butir item tersebut valid. Sebaliknya jika di dapat nilai korelasi item lebih kecil dari nilai $r$ tabel $(=0,31)$, maka butir item tersebut dinyatakan tidak valid atau gugur.

Hasil perhitungan validitas item skala kemampuan adaptasi trhadap kebisingan disajikan pada tabel berikut

\section{Tabel 5.}

Validitas skala kemampuan adaptasi terhadap kebisingan

\begin{tabular}{|c|c|c|c|c|}
\hline \multirow{2}{*}{$\begin{array}{l}\mathbf{N} \\
\mathbf{0}\end{array}$} & \multirow[t]{2}{*}{ Indikator } & \multicolumn{2}{|c|}{ Validitas } & \multirow[t]{2}{*}{ Indeks Validitas } \\
\hline & & Valid & Tidak Valid & \\
\hline 1 & Volume & $1,4,7,10,13,16,19,22,28$ & 25 & $0,3344-0,6577$ \\
\hline 2 & Perkiraan & $2,5,8,14,20,23,26,29$ & 11,17 & $0,3347-0,7379$ \\
\hline 3 & Kontrol & $3,18,21,24,27,30$ & $6,9,12,15$ & $0,3285-0,4750$ \\
\hline & OTAL & 23 & 7 & - \\
\hline
\end{tabular}

Tabel hasil perhitungan validitas di atas menunjukkan bahwa skala kemampuan adaptasi terhadap kebisingan yang berjumlah 30 item diperoleh 23 item valid dan 7 item tidak valid. 
Hasil perhitungan validitas item skala stres kerja disajikan pada tabel berikut

Tabel 6.

Validitas skala stres kerja

\begin{tabular}{|c|c|c|c|c|}
\hline \multirow[t]{2}{*}{ No } & \multirow[t]{2}{*}{ Indikator } & \multicolumn{2}{|c|}{ Validitas } & \multirow[t]{2}{*}{ Indeks Validitas } \\
\hline & & Valid & Tidak Valid & \\
\hline \multirow[t]{2}{*}{1} & $\begin{array}{l}\text { Faktor Intrinsik } \\
\text { dalam pekerjaan } \\
\text { a. Tuntutan Fisik }\end{array}$ & $\begin{array}{l}1,7,13,19,25,31 \\
37,43,49,55\end{array}$ & 61,67 & $0,3345-0,7221$ \\
\hline & b. Tuntutan Tugas & $\begin{array}{l}2,8,14,20,26 \\
32,38,44,62\end{array}$ & $\begin{array}{c}50 \\
56,68\end{array}$ & $0,3404-0,6082$ \\
\hline 2 & $\begin{array}{l}\text { Peran individu } \\
\text { dalam organisasi }\end{array}$ & $\begin{array}{l}3,9,15,39,45 \\
51,63,69\end{array}$ & $\begin{array}{l}21,27 \\
33,57\end{array}$ & $0,3244-0,6655$ \\
\hline 3 & $\begin{array}{l}\text { Pengembangan } \\
\text { karir }\end{array}$ & $\begin{array}{l}4,10,16,22,28 \\
46,52,64,70\end{array}$ & $\begin{array}{l}34,40 \\
58\end{array}$ & $0,3281-0,7151$ \\
\hline 4 & $\begin{array}{l}\text { Hubungan dalam } \\
\text { pekerjaan }\end{array}$ & $\begin{array}{l}5,11,17,23,29 \\
35,53,59,65,71\end{array}$ & 41,47 & $0,3209-0,6574$ \\
\hline 5 & $\begin{array}{l}\text { Struktur dan iklim } \\
\text { organisasi }\end{array}$ & $\begin{array}{l}18,24,36,42, \\
48,54,60,66,72 \\
\end{array}$ & $\begin{array}{c}6,12 \\
30 \\
\end{array}$ & $0,3300-0,6107$ \\
\hline & TOTAL & 55 & 17 & - \\
\hline
\end{tabular}

Tabel hasil perhitungan validitas di atas menunjukkan bahwa skala stres kerja yang berjumlah 72 item, diperoleh 55 item valid dan 17 item tidak valid.

Perhitungan reliabilitas pada penelitian ini dengan menggunakan program komputer SPSS 11.0 for Windows.

Hasil perhitungan reliabilitas indikator skala kemampuan adaptasi terhadap kebisingan disajikan pada tabel berikut:

Tabel 7.

Reliabilitas indikator skala kemampuan adaptasi terhadap kebisingan

\begin{tabular}{ccccc}
\hline No & Indikator & Alpha (ri) & r tabel & Status \\
\hline $\mathbf{1}$ & Volume & 0,7987 & 0,31 & reliabel \\
$\mathbf{2}$ & Perkiraan & 0,7996 & 0,31 & reliabel \\
\hline $\mathbf{3}$ & Kontrol & $\mathbf{0 , 6 5 4 5}$ & $\mathbf{0 , 3 1}$ & reliabel \\
\hline
\end{tabular}


Perhitungan reliabilitas dengan menggunakan teknik Alpha menunjukkan bahwa koefisien reliabilitas faktor-faktor kemampuan adaptasi terhadap kebisingan $\left(r_{i}=0,6545-\right.$ $0,7996)$ lebih besar dari $\mathrm{r}$ tabel $(=0,31)$. Dengan demikian dapat dinyatakan bahwa item-item tersebut reliabel untuk setiap faktor.

Sedangkan hasil perhitungan reliabilitas indikator skala stres kerja disajikan pada tabel berikut :

Tabel 8.

Reliabilitas skala stres kerja

\begin{tabular}{|c|c|c|c|c|}
\hline No & Indikator & Alpha $\left(\mathbf{r}_{\mathbf{i}}\right)$ & $\mathbf{r}$ tabel & Status \\
\hline 1 & $\begin{array}{l}\text { Faktor Intrinsik dalam } \\
\text { pekerjaan : } \\
\text { a. Tuntutan Fisik } \\
\text { b. Tuntutan Tugas }\end{array}$ & 0,8163 & 0,31 & Reliabel \\
\hline 2 & $\begin{array}{l}\text { Peran individu dalam } \\
\text { organisasi }\end{array}$ & 0,7859 & 0,31 & Reliabel \\
\hline 3 & Pengembangan karir & 0,6752 & 0,31 & Reliabel \\
\hline 4 & $\begin{array}{l}\text { Hubungan } \\
\text { pekerjaan }\end{array}$ & 0,7652 & 0,31 & Reliabel \\
\hline 5 & $\begin{array}{lll}\begin{array}{l}\text { Struktur } \\
\text { organisasi }\end{array} & \text { dan } & \text { iklim } \\
\end{array}$ & 0,6550 & 0,31 & Reliabel \\
\hline
\end{tabular}

Perhitungan reliabilitas Alpha di atas menunjukkan bahwa koefisien reliabilitas faktor-faktor stres kerja $\left(r_{i}=0,6550-0,8163\right)$ lebih besar dari $r$ tabel $(=0,31)$. Dengan demikian dapat dinyatakan bahwa item-item tersebut reliabel untuk setiap faktor.

Adapun hasil dari uji reliabilitas kedua skala dapat dilihat pada tebel berikut ini: 
Tabel 9.

Uji reliabilitas skala kemampuan adaptasi terhadap kebisingan

dengan skala stres kerja

\begin{tabular}{clccc}
\hline No & \multicolumn{1}{c}{ Skala } & Alpha (ri) & r tabel & Status \\
\hline $\mathbf{1}$ & $\begin{array}{l}\text { Kemampuan Adaptasi } \\
\text { terhadap Kebisingan } \\
\end{array}$ & 0,8270 & 0,31 & Reliabel \\
& $($ skala A) & & & \\
\hline $\mathbf{2}$ & Stres kerja (skala B) & $\mathbf{0 , 9 2 2 6}$ & $\mathbf{0 , 3 1}$ & Reliabel \\
\hline
\end{tabular}

Dari hasil tabel diatas maka faktor-faktor yang terdapat dalam skala kemampuan adaptasi terhadap kebisingan maupun skala stres kerja dinyatakan telah memiliki status reliabel atau andal, sehingga sudah siap untuk digunakan dalam penelitian.

\section{Metode Analisa Data}

Metode analisis data dalam penelitian ini menggunakan teknik analisa korelasi Product Moment, yaitu teknik pengukuran untuk mencari tingkat hubungan dan membuktikan hipotesis hubungan dua variabel.

\section{H a $\mathrm{s}$ i 1}

\section{Deskripsi Data}

Deskripsi data akan memberikan gambaran tentang keadaan distribusi skor skala pada kelompok subyek penelitian. Dalam penelitian ini deskripsi data yang akan dijabarkan adalah deskripsi data variabel kemampuan adaptasi terhadap kebisingan dan stres kerja yang dikelompokkan menjadi tinggi dan rendah. Untuk mempermudah pemahaman data yang diperoleh, maka peneliti menggunakan rumus T Score..$^{22}$ Adapun rumusnya sebagai berikut:

\footnotetext{
${ }^{22}$ Saifuddin Azwar, Reliabilitas dan Validitas, 4 ed. (Yogyakarta: Pustaka Pelajar, 2003). 156.
} 


$$
\mathrm{T} \text { Score }=50+10\left(\frac{X-\bar{X}}{S D}\right)
$$

Keterangan :

$\mathrm{X} \quad=$ Jumlah item valid

$\mathrm{X} \quad=$ Mean skor kelompok

$\mathrm{SD} \quad=$ Standar deviasi skor kelompok

Apabila nilai T Score $>50$ termasuk kategori tinggi/positif dan sebaliknya jika nilai $\mathrm{T}$ Score $<50$ termasuk kategori rendah/negatif.

Hasil perhitungan kedua skala yang sudah dikategorisasikan adalah sebagai berikut :

1. Skala kemampuan adaptasi terhadap kebisingan

Hasil kategori data skala kemampuan adaptasi terhadap kebisingan disajikan pada tabel berikut :

Tabel 10.

Kategori data skala kemampuan adaptasi terhadap kebisingan

\begin{tabular}{lcc}
\hline \multicolumn{1}{c}{ Kategori } & Frekuensi & Prosentase \\
\hline Baik & 23 & $38,3 \%$ \\
Kurang baik & 37 & $61,6 \%$ \\
\hline \multicolumn{1}{c}{ Jumlah } & 60 & $100 \%$ \\
\hline
\end{tabular}

Tabel tersebut menunjukkan bahwa yang memiliki kemampuan adaptasi yang baik terhadap kebisingan sebesar 38,3 \% (23 orang), sedangkan yang memiliki kemampuan adaptasi yang kurang baik terhadap kebisingan sebesar 61,6 \% (37 orang).

2. Skala stres kerja

Hasil kategori data skala stres kerja disajikan pada tabel berikut : 
Tabel 11.

Kategori data skala Stress kerja

\begin{tabular}{rcc}
\hline Kategori & Frekuensi & Prosentase \\
\hline Tinggi & 32 & $53,3 \%$ \\
Rendah & 28 & $46,6 \%$ \\
\hline Jumlah & 60 & $100 \%$ \\
\hline
\end{tabular}

Tabel tersebut menunjukkan bahwa 53,3 \% subjek penelitian mengalami stres kerja yang tinggi (32 orang), sedangkan sisanya 46,6\% subyek penelitian mengalami stres kerja yang rendah (28 orang).

\section{Analisis Data}

Teknik analisis data yang digunakan untuk menguji data dalam penelitian ini adalah analisa Product Moment. Untuk proses pengolahan data, perhitungan statistiknya menggunakan program komputer SPSS 11.0 for Windows.

Interpretasi hasil uji statistik yaitu dengan melihat taraf kepercayaan atau kemaknaan yang ditunjukkan oleh indeks kesalahan yang mungkin terjadi yang disebut dengan probabilitas error (error probability) atau biasa disingkat dengan p.e atau $\mathrm{p}$ saja. Taraf kepercayaan secara konvensional berkisar antara 0,05 sampai 0,01. Apabila hasil uji statistik didapatkan harga $\mathrm{p}>0,05$ berarti tidak signifikan, harga $\mathrm{p} \leq 0,05$ berarti signifikan dan $\mathrm{p}<$ 0,01 berarti sangat signifikan. ${ }^{23}$

Tabel 12.

Korelasi antara Kemampuan Adaptasi terhadap Kebisingan dengan Stres Kerja

\begin{tabular}{cccc}
\hline $\begin{array}{c}\text { Koefisien Korelasi } \\
(\mathrm{r})\end{array}$ & $\begin{array}{c}\text { Koefisien Determinan } \\
\left(\mathbf{r}^{2}\right)\end{array}$ & $\begin{array}{c}\text { Peluang Ralat } \\
(\mathrm{p})\end{array}$ & Kesimpulan \\
\hline$-0,359$ & $\mathbf{0 , 1 2 8 8}$ & 0,005 & $\begin{array}{c}\text { Sangat } \\
\text { signifikan }\end{array}$ \\
\hline
\end{tabular}

Berdasarkan hasil analisa data tersebut, maka dapat di buat kesimpulan bahwa ada hubungan negatif yang sangat signifikan antara kemampuan adaptasi terhadap kebisingan

\footnotetext{
${ }^{23}$ Tulus Winarsunu, Statistik dalam Penelitian Psikologi Pendidikan. 20
} 
dengan stres kerja karyawan $(r=-0,359, p=0,005)$. Artinya jika kemampuan adaptasi baik terhadap kebisingan maka stres kerja rendah dan sebaliknya jika kemampuan adaptasi kurang baik terhadap kebisingan maka stres kerja cenderung tinggi.

Adapun koefisien determinan $\left(\mathrm{r}^{2}\right)$ kemampuan adaptasi terhadap kebisingan adalah sebesar 0,1288. Dengan demikian sumbangan efektif dari kemampuan adaptasi terhadap kebisingan dengan stres kerja karyawan sebesar 12,88 \%, sedangkan sisanya 87,12 \% berasal dari variabel lain.

\section{Diskusi}

Dari penelitian yang telah dilakukan, maka didapatkan hasil bahwa ada hubungan negatif yang sangat signifikan antara kemampuan adaptasi terhadap kebisingan dengan stres kerja karyawan bagian produksi PT. Hendratna Plywood $(r=-0,359, p=0,005)$. Artinya jika kemampuan adaptasi terhadap kebisingan baik maka stres kerja karyawan rendah, dan sebaliknya jika kemampuan adaptasi terhadap kebisingan kurang baik maka stres kerja karyawan cenderung tinggi.

Stres kerja merupakan suatu kondisi ketegangan terhadap situasi dan kondisi di dalam lingkungan kerja yang mempengaruhi emosi, proses berpikir dan kondisi seseorang. Setiap aspek di pekerjaan dapat menjadi pembangkit stres. Karyawan yang menentukan sejauh mana situasi yang dihadapi merupakan situasi stres atau tidak. Menurut Munandar, ${ }^{24}$ sumber stres yang menyebabkan seseorang tidak berfungsi optimal atau yang menyebabkan seseorang jatuh sakit, tidak saja datang dari satu macam pembangkit stres saja tetapi dari beberapa pembangkit stres, sebagian besar dari waktu manusia bekerja. Karena itu, lingkungan pekerjaan mempunyai pengaruh yang besar terhadap kesehatan seseorang yang bekerja.

Kondisi fisik lingkungan kerja yang bising merupakan salah satu pembangkit stres. Munandar ${ }^{25}$ mengatakan bahwa bising selain dapat menimbulkan gangguan sementara atau tetap pada alat pendengaran, juga dapat merupakan sumber stres yang menyebabkan peningkatan dari kesiagaan dan ketidak seimbangan psikologis. Selain itu Ivancevich dan

\footnotetext{
${ }^{24}$ A. S Munandar, Psikologi Industri dan Organisasi. 380.

${ }^{25}$ Ibid. 381
} 
Matteson (1980)26 berpendapat bahwa bising yang berlebih (sekitar 80 desibel) yang berulangkali di dengar, untuk jangka waktu lama, dapat menimbulkan stres.

Stres kerja dapat diungkapkan melalui gejala-gejala stres kerja yang meliputi gejala fisiologis, gejala psikologis, dan gejala perilaku. Pada gejala fisiologis ditandai dengan perubahan dalam metabolisme tubuh, meningkatnya laju detak jantung dan pernapasan, meningkatnya tekanan darah, dan timbul sakit kepala. Gejala psikologis ditandai dengan berkurangnya kepuasan kerja, cemas, mudah marah, bosan dan suka menunda-nunda. Sedangkan gejala perilaku ditandai dengan perubahan dalam produktivitas, sering absensi, perubahan dalam pola makan, meningkatnya merokok, bicara cepat dan mengalami gangguan tidur.

Dari hasil deskripsi data menunjukkan bahwa kategori tinggi untuk stres kerja sebesar $53,3 \%$, sedangkan stres kerja rendah sebesar 46,6 \%. Ini menunjukkan bahwa stres kerja tinggi pada karyawan bagian produksi PT. Hendratna Plywood lebih banyak bila dibanding dengan stres kerja rendah.

Kebisingan merupakan salah satu sumber stres kerja. Adapun pengertian kebisingan adalah bunyi yang tidak dikehendaki oleh telinga karena mengganggu dan menjengkelkan. Dalam lingkungan industri, perkantoran dan situasi-situasi kerja lainnya, bunyi merupakan salah satu faktor pengganggu (distractor) yang paling umum. Karyawan yang bekerja setiap hari mendengar bunyi-bunyian di tempat kerjanya, baik yang ditimbulkan dari pekerjaannya, pekerjaan orang lain atau situasi di tempat kerja. Bunyi - bunyi yang ada di lingkungan di terima dan di proses oleh telinga.

Kebisingan merupakan salah satu jenis rangsang lingkungan yang dapat di respon berbeda oleh setiap individu. Dimana individu yang dapat melakukan perubahan respon terhadap rangsang lingkungan yaitu kebisingan, maka dapat dikatakan bahwa ia memiliki kemampuan adaptasi terhadap kebisingan. Hal ini sesuai dengan pendapat Sonenfeld $(1966)^{27}$, bahwa adaptasi menunjukkan pada perubahan respon seseorang atas rangsang (bukan perubahan pada rangsangnya). Individu yang dapat melakukan perubahan respon terhadap lingkunganya dengan benar maka tidak akan mengalami stres. Hal ini mengacu

\footnotetext{
${ }^{26}$ Ibid. 382.

${ }^{27}$ Oman Sukmana, Dasar-dasar Psikologi Lingkungan. 45.
} 
dengan pendapat Anoraga ${ }^{28}$ bahwa kemampuan adaptasi diperlukan agar seseorang dapat menghadapi stresnya dengan baik.

Faktor pengendalian pada kebisingan merupakan salah satu yang mempengaruhi kemampuan adaptasi terhadap kebisingan. Karyawan yang tidak bisa mengendalikan kebisingan yang dilingkungannya maka dia akan menjadi tidak berdaya dan membiarkan saja bising itu walaupun stresnya bertambah besar, ini menunjukkan bahwa karyawan tidak melakukan penyesuaian atau adaptasi terhadap rangsang yang ada dilingkungannya. Hal ini sesuai dengan pendapat Sukmana ${ }^{29}$ yang mengatakan bahwa tidak adanya kendali pada kebisingan akan menimbulkan stres yang jika berlangsung lama pada akhirnya bisa menimbulkan reaksi learned helplessness (ketidakberdayaan yang dipelajari).

Volume suara juga merupakan salah satu faktor yang mempengaruhi kemampuan adaptasi terhadap kebisingan. Dimana diketahui volume suara di lingkungan kerja karyawan bagian produksi PT. Hendratna Plywood rata-rata di atas $90 \mathrm{~dB}$. Karyawan yang memiliki kemampuan adaptasi yang baik, maka ia mampu menerima volume suara tersebut dengan cara melakukan penyesuaian terhadap kebisingan tersebut. Salah satu caranya adalah dengan menggunakan alat penyumbat telinga.

Selain itu, karyawan yang dapat memprediksi kebisingan yang terjadi di lingkungannya, maka dapat dikatakan telah memiliki kemampuan adaptasi yang baik terhadap kebisingan. Hal ini karena karyawan sudah terbiasa dengan kebisingan yang ada di lingkungan kerjanya, sehingga dia sudah dapat memperkirakan adanya suatu kebisingan yang ada di lingkungan kerjanya.

Hasil deskripsi data kemampuan adaptasi terhadap kebisingan menunjukkan bahwa karyawan yang mempunyai kemampuan adaptasi baik terhadap kebisingan sebesar 38,3 \%, sedangkan karyawan yang mempunyai kemampuan adaptasi kurang baik terhadap kebisingan sebesar $61,6 \%$. Ini menggambarkan bagaimana kemampuan adaptasi terhadap kebisingan para karyawan bagian produksi PT. Hendratna Plywood. Karyawan yang mempunyai kemampuan adaptasi baik terhadap kebisingan lebih banyak bila di banding dengan karyawan yang mempunyai kemampuan adaptasi kurang baik terhadap kebisingan.

\footnotetext{
${ }^{28}$ Pandji Anoraga, “Psikologi kerja," Jakarta: PT. Rineka Cipta, 1992. 108.

${ }^{29}$ Oman Sukmana, Dasar-dasar Psikologi Lingkungan. 83.
} 
Hasil dari penelitian ini menunjukkan bahwa kemampuan adaptasi terhadap kebisingan memberikan sumbangan efektif sebesar 12,88 \% terhadap stres kerja karyawan bagian produksi PT. Hendratna Plywood, sedangkan 87,12 \% dipengaruhi oleh variabelvariabel lain seperti tuntutan fisik dapat berupa cahaya, bau dan udara yang kurang nyaman, tuntutan tugas berupa beban kerja yang berlebih atau sedikit, peran individu dalam organisasi yang tidak sesuai dengan job descriptionnya, tidak adanya kesempatan untuk mengembangan karier di dalam perusahaan dan tidak adanya keterlibatan karyawan dalam mengambil keputusan atau inisiatif karyawan tidak dihiraukan. Hal ini mengacu pada pendapat Munandar ${ }^{30}$ bahwa sumber-sumber stres terdiri dari faktor-faktor intrinsik dalam pekerjaan yaitu tuntutan fisik dan tuntutan tugas, peran individu dalam organisasi, pengembangan karier, hubungan dalam pekerjaan dan struktur dan iklim organisasi.

\section{Kesimpulan}

Berdasarkan hasil analisis data, maka dapat disimpulkan bahwa ada hubungan negatif yang sangat signifikan antara kemampuan adaptasi terhadap kebisingan dengan stres kerja karyawan bagian produksi PT. Hendratna Plywood. Artinya jika karyawan mempunyai kemampuan adaptasi yang baik terhadap kebisingan maka stres kerja rendah. Sebaliknya apabila karyawan mempunyai kemampuan adaptasi yang kurang baik terhadap kebisingan maka karyawan cenderung lebih mudah mengalami stres kerja, tercermin dari skor skala stres kerja yang tinggi. Dari penelitian ini dapat diketahui bahwa kemampuan adaptasi terhadap kebisingan memberikan sumbangan efektif sebesar $12,88 \%\left(r^{2}=0,1288\right)$ terhadap stres kerja karyawan, sedangkan 87,12 \% sumbangan variabel lain yang tidak diteliti. Saran

Pada penelitian diketahui bahwa kemampuan adaptasi cenderung kurang baik terhadap kebisingan, dan stres kerja karyawan cenderung tinggi. Untuk itu diharapkan kepada pihak manajemen perusahaan agar berupaya untuk mengurangi stres kerja karyawan dengan cara mengadakan program-program kesehatan bagi karyawan, training atau outbond.

Diharapkan para karyawan dapat berusaha untuk menyesuaikan diri dengan kondisi lingkungan kerja yang mengakibatkan stres. Agar dapat mempunyai kemampuan adaptasi

${ }^{30}$ A. S Munandar, Psikologi Industri dan Organisasi. 381. 
yang baik terhadap kebisingan, dalam mengantisipasi di lingkungan kerja, karyawan dapat melakukan pengendalian kebisingan dengan cara selalu memakai alat peredam/sumbat telinga disaat bekerja. Selain itu karyawan diharapkan dapat aktif dalam mengikuti program-program kesehatan yang diadakan perusahaan.

Saran bagi peneliti selanjutnya adalah untuk lebih memperhatikan dalam pembuatan skala stres kerja yaitu dengan menggunakan indikator-indikator stres kerja yang terbatas (tidak luas) dan disesuaikan dengan variabel penelitian (variabel bebas). Selain itu stres kerja juga dapat dihubungkan dengan variabel-variabel lain yang sesuai dengan kondisi ataupun permasalahan dari tempat yang ingin diteliti.

\section{Kepustakaan}

A. S Munandar. Psikologi Industri dan Organisasi. Jakarta: Penerbit Universitas Indonesia (UIPress), 2001.

Anoraga, Pandji. "Psikologi kerja." Jakarta: PT. Rineka Cipta, 1992.

ARDANI, Tristadi Ardi, dan Sri Rahayu Partosuwido. "Hubungan antara persepsi tentang keselamatan kerja dan kesehatan kerja dengan stres kerja pada pekerja di Pertamina Unit Pengolahan (UP) VI Balongan Indramayu Jawa Barat." Jurnal APIO, 2005.

Arikunto, Suharsimi. "Metode penelitian." Jakarta: Rineka Cipta, 2002.

Diahsari, Erita Y. "Kontribusi stres pada produktivitas kerja." Jurnal ANIMA 16, no. 4 (2001).

E. Poerwanti. Dimensi-dimensi Riset Ilmiah. Malang: UMM Press, 2000.

Evans, Gary W, dan Dana Johnson. "Stress and open-office noise." Journal of applied psychology 85, no. 5 (2000): 779.

F.N. Kerlinger. Asas-asas Penelitian Behavioral. Yogyakarta: Gadjah Mada University Press, 2003.

M. Lucas, dan K. Wilson. Memelihara Gairah Kerja. Jakarta: Arcan, 1992.

National Safety Council. Manajemen Stres. Jakarta: EGC, 2004.

Oman Sukmana. Dasar-dasar Psikologi Lingkungan. Malang: Bayu Media \& UMM Press, 2003.

Saifuddin Azwar. Reliabilitas dan Validitas. 4 ed. Yogyakarta: Pustaka Pelajar, 2003.

- - - Sikap Manusia. Teori dan Pengukurannya. 2 ed. Yogyakarta: Pustaka Pelajar, 2003.

S. Nahhari. "Tingkat Stres Kerja pada Karyawan Unit Pengolahan V Pertamina Balikpapan." Skripsi, Fakultas Psikologi Universitas Muhammadiyah Malang, 2003.

Sarlito W. Sarwono. Psikologi Lingkungan. Jakarta: PT. Gramedia Widiasarana Indonesia, 1995.

S.P. Robbins. Perilaku Organisasi. Jakarta: PT INDEKS Kelompok Gramedia, 2003.

Suharsimi Arikunto. Prosedur Penelitian Suatu Pendekatan Praktek. Edisi revisi IV. Jakarta: PT. Rineka Cipta, 2002.

Tulus Winarsunu. Statistik dalam Penelitian Psikologi Pendidikan. Malang: UMM Press, 2002. 